\title{
THE USE OF ONLINE TECHNOLOGIES IN THE PROCESS OF TRAINING FUTURE MUSIC TEACHERS
}

\author{
Larisa Varnavskaya, Margarita Viktorova, Liliana Rymar
}

\begin{abstract}
Modern graduates of higher educational institutions should be able to independently process information and be ready to acquire and use knowledge throughout their professional life. The actual task of education in the conditions that have formed in the world is the development of new educational technologies, which are added almost every year. The virtual world is becoming more and more diverse. The use of digital platforms is a pressing issue at a time when almost all information and activities are moving into the virtual world.

The article substantiates the use of digital platforms Zoom and Padlet, which are new in teaching technology. The issues of implementation of educational technologies in the process of training future teachers of musical art are considered. The capabilities of the web interface, which is the Padlet interactive whiteboard, which makes it quite popular in the education system, are analyzed. Using the capabilities of a virtual online whiteboard refers to new educational technologies. In-depth capabilities of work on the Zoom platform are shown. It has been shown, that the use of a multifunctional service affects the development of communicative and organizational skills of students. The process of connecting digital platforms Zoom and Padlet with music computer technologies is shown with specific examples. The organizational issues of conducting a practical lesson on arranging musical works using digital platforms are considered. The stages of preparation for arrangement are presented. An algorithm for creating a phonogram of a school song using Zoom and Padlet technologies, individual work and work in groups, which is one of the main issues of modern education, is shown. At the same time, the development of an integrated approach to the organization of effective educational activities in the conditions of an information and educational environment is relevant at the present time
\end{abstract} Keywords: digital platforms, virtual whiteboard, online learning, musical arrangement, creative tasks, algorithm

How to cite:

Varnavskaya, L., Viktorova, M., Rymar, L. (2021). The use of online technologies in the process of training future music teachers. ScienceRise: Pedagogical Education, 6 (45), 3-7. doi: http://doi.org/10.15587/2519-4984.2021.246524

(C) The Author(s) 2021

This is an open access article under the Creative Commons CC BY license hydrate

\section{Introduction}

Possession of information and communication technologies should become one of the most important competencies of modern teachers in today's life, when learning is online and the requirements for training are increasing. Former approaches to education based on conventional knowledge transfer do not work in a rapidly changing world. Only age-related, continuing education that combines knowledge and skills that encourages interdisciplinarity, fosters social tolerance, increases accessibility and makes extensive use of new telecommunications tools can adapt people to the modern world [1].

Therefore, the problem of developing and implementing modern educational technologies that will help improve the quality of education becomes paramount in the new conditions, when the modern educational environment is formed on the basis of virtual culture, distance communication and new requirements for educational services.

\section{Literary review}

The Regulations on Distance Education and the Concept of Distance Education Development in Ukraine regulate the rights and responsibilities of participants in the educational process [2]

Distance learning includes a set of specific activities, which include:

- means of providing educational material to a student;

- means of monitoring student performance;

- means of interactive cooperation between teacher and student;

- the ability to quickly replenish the course with new information [3].

The use of online platforms in distance learning is developing during the pandemic, when the issue of continuing education in quarantine is acute.

G. Polushkina in her work "Learning situations as a means of forming universal learning activities using interactive whiteboards" proves that an interactive whiteboard allows all participants in the learning process to "engage in cognitive activity, saves time in class, provides clarity, provides feedback, brings novelty to educational activities "[4]. The use of interactive whiteboards in educational activities allows to draw attention to the learning process at all stages of the modern lesson: up- 
dating knowledge, explaining new material, generalizing and consolidating the studied material, systematization of knowledge, testing, reflection. Using an interactive whiteboard, a teacher can provide creative lessons, demonstrate material much more effectively, organize students' work during a lesson.

T. Masharova agrees with this and focuses on creating learning situations in English lessons using an interactive whiteboard and draws positive conclusions about the feasibility of its use in the educational process [5].

However, V. Belopolska in the work "Distance Learning: Problems and Prospects" draws attention to the shortcomings of the distance learning system, which includes: lack of technical capabilities (Internet speed), lack of computer training for participants in the educational process, insufficient development of educational electronic complexes and manuals, etc.

M. Nikolaenko in the work "Interactive whiteboard: theory and practice" [6] proves the need to use an interactive whiteboard to increase student motivation, enhance their cognitive activity, development of communication skills, simultaneous use of various materials. This is the approach we used during a practical lesson with the use of online technologies.

The scientific literature, materials of scientific and practical conferences provide advice on the use of digital platforms in teaching mathematics, computer science, physics, foreign languages, etc., but there is almost no use of digital platforms in music education.

Training a future music teacher involves not only mastering knowledge of art and music, but also mastering modern digital information technology to bring students information from art disciplines and involve them in search and analysis, development of creative thinking, ability to work in groups, forming, expressing and defending one's own opinion, consolidating acquired musical skills and abilities.

Based on the fact that gadgets and their software form the information field of all participants in the educational process, we will focus on digital technologies, which are still insufficiently used in the process of preparing future music teachers to arrange musical works.

Arranging musical works (in our case school songs) is a creative process, in which both one person and a group of pupils or students can take part. In collective work communicative skills are developed, creative problems arise and are solved, a leader is singled out (not always the one who is the leader in training).

Issues of arranging musical works are covered in the works of T. Zatyamina, I. Krasilnikova, L. Stolyarchuk, which deal with the arrangement of instrumental, choral and vocal music in face-to-face communication. But the issue of arranging music with a synthesizer using modern digital platforms has not been given enough attention.

\section{Aim and tasks of the study}

The aim of the work is to highlight the features of the digital platform Zoom and the Padlet service; their practical use in the process of training future music teachers.
To achieve this goal, the following tasks were set:

1 . To show the possibilities of organizing work in distance learning.

2. To provide an algorithm for working with online tools.

3. To explain the combination of digital platforms with computer music technology in the process of arranging music.

4. To explain the features of individual and group work during distance learning.

\section{Materials and methods}

The newest digital platforms that can be used for online learning include the Zoom platform and the Padlet interactive whiteboard. Consider the capabilities of each digital platform separately.

Information resources provide different definitions to the Padlet interactive whiteboard. Some point out that Padlet is a virtual board, on which you can place text notes, images, photos (including from the webcam), files and links to external resources [7]. Others believe that Padlet (https://uk.padlet.com/) is a universal online board (online wall) with an intuitive interface that is easy to master and easy to use in the educational process. It can be used for project work, individual tasks or as a tool for communicating and collecting information from all students in one place [8]. Still others define Padlet (http://ru.padlet.com/) as a multimedia resource for creating, sharing, and storing information. This is a virtual wall, to which you can attach photos, files, links to the Internet, notes. This can be a private wall project, a moderated wall with several participants who will fill it with information or available for reading and editing by any user platform for information exchange [9].

Summarizing all the definitions, it can be stated, that the online board Padlet in the educational process is a learning tool that can be used to provide creative tasks using links to the Internet; a multimedia resource for collective editing of the provided information; a platform for the exchange of information and capabilities to combine text, images, video, audio in a single interactive format.

Thus, the didactic possibilities of the virtual board are quite wide. These are: a website that allows you to communicate with other users through messages; links to information resources; multimedia capabilities and other content.

Because Padlet is a cloud service, a user only needs to have Internet access and a browser to work. The board is open for messages to anyone who has a link to it. However, a user can only add and edit their own posts, while a moderator who created the board can manage all posts.

You can take full advantage of the Padlet virtual whiteboard when working on the Zoom digital platform

This digital platform is a service for video conferencing, online classes and all distance education. The Zoom digital platform allows you to conduct individual and group lessons, where users can join it from any device: computer, tablet or phone. Zoom has a chat with a board, on which you can share information. When communicating on this platform, you can demonstrate presentations, and use audio and video materials to ex- 
plain a new topic. The advantages are: the ability to see everyone who is in class; moderator control of participants' microphones (turn on/off the microphone); preparation of the meeting in advance (an event can be scheduled for a certain time for permanent entry, and you can create the same link for entry at any time); recording a conference (lesson, lecture, event) on a computer or in the cloud; the opportunity to group students and work separately with each group.

Therefore, the use of the Zoom digital platform is appropriate for distance and blended learning.

These technologies were chosen to conduct classes with future teachers of music art, teaching them to arrange music with a synthesizer. Careful preparation of a teacher for such classes takes a lot of time, but the more interesting and diverse will be the implementation of creative tasks, the sooner communication will be established in each group, more students will be involved in the arranging process.

The algorithm for arranging a school song was determined in the previous lesson. It consists of certain points, where one of the first was the study of the melody of the song and the selection of a certain rhythm (style) to it. To accomplish this task, we divided a group of 14 students into two subgroups of 7 people each, placing them in two session halls at Zoom. The students were offered a choice of modern rhythms (styles) and academic. Rhythms that can be used in arranging a certain school song were chosen by trial and error. This issue was discussed in groups, while the teacher could go to one and the other session hall and hear the statements of the students. The students at this time could only hear members of their group. Then the groups were reunited, and the rhythm (style) of the future arranged song was determined by voting. Informational consent was obtained from all study participants.

Thus, the division into groups and the work in them contributed to the development of communication, and defending the views of the group revealed leaders in each group. In the process of discussion, the students acquire communicative and organizational skills, learn to construct a dialogue, distribute roles in it, master the elements of public speaking.

The teacher recorded the chosen style in the synthesizer's memory.

In order to continue arranging a school song, it is necessary, according to the arrangement algorithm, to choose timbres (musical instruments), which write melody, undertones, verses and choruses on the synthesizer tracks according to the content of the musical work.

Prior to the school song arranging session, sites were found to display sounds and videos of musical instruments that were supposed to be used in the arrangement and those that were included in the program of the electronic instrument - synthesizer. Having created two virtual Padlet whiteboards (the main and its copy), links to these sites were placed on them, so that the students (and in the future their students) could choose to their liking and musical preferences those musical instruments that are more suitable for arranging songs, reflect the idea of the composer and correspond to the content of the song.
Initially, the students chose the timbres of musical instruments individually and expressed their own opinions using the Padlet virtual whiteboard.

In the next stage, the students, in the automatic mode of the Zoom platform, were divided into two groups. Then the method of "brainstorming" was used. In their session hall, each group listened to the sound of instruments, watched video clips of what certain musical instruments looked like, and discussed the options of musical instruments (timbres), needed to reveal the composer's idea and the song content. The students found out whether the timbres of musical instruments correspond to the age characteristics of trainees (voice range, psychological aspects of perception of musical works). The options, selected by each group, were written on the virtual whiteboard and put up for collective discussion.

Through discussion and voting, a chart was written on the Padlet board, using tools (timbres) to record a school song.

In order to record the song in the synthesizer's memory, preparatory work was done, and each student was sent the main panel of the synthesizer, which shows and describes all the buttons and keys, needed to record the work of arranging a piece of music. The conducted frontal survey showed the independent work of the students in preparation for the practical lesson.

The teacher recorded the selected musical instruments (timbres) on the synthesizer tracks at the suggestion of the students. Due to the fact that each key corresponds to a different percussion instrument, those that decorate the arranged school song and add a certain color to the music were collectively selected.

\section{Results of the study and their discussion}

The work, carried out in a practical lesson with the use of online platforms, has shown its usefulness: the students have learned to work with digital technologies individually and combine conclusions into a collective result that develops communication skills; understand how to host music computing technology on digital platforms; were able to combine the process of selecting the timbres of instruments with the arrangement of a musical work.

Thus, during the practical lesson the students were:

- shown the methods and techniques of using the Zoom platform and the Padlet service in the process of arranging a piece of music;

- given the methods of work on communication development, sequence of tasks.

Insufficient equipment of students with individual computer music equipment in the form of a synthesizer does not allow to perform a number of creative tasks: selection of instrument timbres, recording in the memory of the instrument. However, the solution to this problem depends on creating the necessary conditions for educational activities of all participants: the preparation of methodological and didactic materials on the use of online technologies, improving material conditions, finding new approaches to the use of digital platforms.

\section{Conclusions}

1. The study shows that in the conditions of distance learning it is possible to use digital platforms Zoom and Padlet in combination with musical computer tech- 
nologies, which are a synthesizer - electronic musical instrument for arranging musical works.

2. The algorithm of work with online tools is given, and features of individual and group work in the process of distance learning are shown.
3. The combination of services with music computer technologies in the process of arranging music works is explained.

4. Features of individual and group work during distance learning are shown.

\section{References}

1. Vsemirnaya deklaratsiya o vysshem obrazovanii dlya XXI veka: podkhody i prakticheskie mery ot 9 oktyabrya 1998 goda (2021). Available at: http://www.conventions.ru/view_base.php?id=1496

2. Dystantsiina osvita. Ministerstvo osvity i nauky Ukrainy. Available at: https://mon.gov.ua/ua/osvita/visha-osvita/distancijna-osvita Last accessed: 08.05.2021

3. Dystantsiina osvita. Vyshcha osvita. Available at: http://vnz.org.ua/dystantsijna-osvita/pro Last accessed: 20.05 .2021

4. Polushkina, G. F. (2017). Uchebnye situatsii kak sredstvo formirovaniya universalnykh uchebnykh deistvii s primeneniem sredstv interaktivnoi doski. Kontsept, 9, 49-53. Available at: http://e-koncept.ru/2017/171020.htm

5. Masharova, T. V., Polushkina, G. F. (2016). Interaktivnaya doska kak sredstvo realizatsii tekhnologii mediaobrazovaniya. Obrazovanie v Kirovskoi oblasti, 3 (39), 30-35.

6. Nikolaienko, M. (2018). Interaktyvna doshka: teoriia i praktyka. Sumy, 94. Available at: http://www.soippo.edu.ua/ images/Новини/2018/08/09/novost1/Інтерактивна_дошка_теорія_і_практика.pdf

7. Padlet. Tsentr navchalnykh ta innovatsiinykh tekhnolohii. Available at: https://ceit.ucu.edu.ua/resursy/instrumenty/servisidlya-spivpratsi/padlet/ Last accessed: 15.05 .2021

8. Yak my krokuiemo do maisternosti (2021). Viddil osvity Ivankivskoi selyshchnoi rady ta KZ ISR «Tsentr profesiinoho rozvytku pedahohichnykh pratsivnykiv». Available at: http://osvita-ivankiv.gov.ua/2021/04/page/5/ Last accessed: 22.05.2021

9. 12 interaktyvnykh onlain-doshok dlia dystantsiinoho navchannia ta spilnoi roboty (2020). Nova osvita. Available at: https://osvitanova.com.ua/posts/4181-12-interaktyvnykh-onlain-doshok-dlia-dystantsiinoho-navchannia-ta-spilnoi-roboty Last accessed: 20.05.2021

10. Onlain-doshky. Available at: https://educationpakhomova.blogspot.com/search/label/Онлайн-дошки

11. Toffler, E. (2002). Shok buduschego. Moscow: OOO «Izdatelstvo ACT», 557.

Received date 07.10.2021

Accepted date 12.11.2021

Published date 30.11.2021

Larisa Varnavska*, PhD, Associate Professor, Department of Methods of Music Education, Singing and Choral Conducting, Kryvyi Rih State Pedagogical University, Haharyna ave., 54, Kryvyi Rih, Ukraine, 50086

Margarita Viktorova, PhD, Associate Professor, Department of Methods of Music Education, Singing and Choral Conducting, Kryvyi Rih State Pedagogical University, Haharyna ave., 54, Kryvyi Rih, Ukraine, 50086

Liliana Rymar, Teacher-Methodologist, Specialist of Highest Category, Energodar Gymnasium No. 2 Energodar City Council of Vasylivka district of Zaporizhia region, Enerhetykiv str., 6, Energodar, Ukraine, 71503

*Corresponding author: Larisa Varnavska, e-mail: larisa.varnavska2017@gmail.com 